\title{
Peter Lorge
}

\section{MILITARY INSTITUTIONS AS A DEFINING FEATURE OF THE SONG DYNASTY}

\begin{abstract}
Although the standard narrative of the Song dynasty is one of civil dominance over the military within the government and society, the institutional development of the government bureaucracy argues for a more nuanced description. The martial side of the government achieved parity in size with the civil side during the Song, exclusive of the army and its bureaucracy. Literati with civil exam degrees filled most of the upper ranks of this martial bureaucracy and therefore occupied themselves with martial, rather than civil, concerns on a day to day basis. A significant number of important civil literati spent most of their time on military tasks and military policy. Functionally then, in contrast to their ideology, many civil literati were militarized by their roles in the bureaucracy while they were controlling it.
\end{abstract}

\section{Keywords}

Song dynasty, China, military, military institutions

\section{INTRODUCTION}

Military institutions changed dramatically over the course of Song history, reflecting not only the dynasty's military fortunes, but also the government's concerns over internal security. From the outset, the dynasty's capital was placed at Kaifeng (Bianjing), a city without natural defenses, in order to ensure the internal security of the dynasty. The centralization of military resources at Kaifeng led directly to Song China's protoindustrial revolution in the eleventh century. ${ }^{1}$ Indeed, much of what made the Song dynasty a precocious technological innovator in world history was due to military concerns. Military affairs also drove much of the dramatic economic and technological development (including military technology) during the Song. ${ }^{2}$

\footnotetext{
Assistant Professor, History Department, Vanderbilt University, e-mail: peter.lorge @ vanderbilt.edu

${ }^{1}$ For Song proto-industrialization see Richard von Glahn, The Economic History of China (Cambridge: Cambridge University Press, 2016), 242-49; Robert M. Hartwell, "A Revolution in the Chinese Iron and Coal Industries During the Northern Sung, 960-1127," Journal of Asian Studies 21.2 (1961-62), 153-62; Robert M. Hartwell, "Markets, Technology and the Structure of Enterprise in the Development of the Eleventh-Century Chinese Iron and Steel Industry," Journal of Economic History 26 (1966): 29-58; Robert M. Hartwell, "A Cycle of Economic Change in Imperial China: Coal and Iron in Northeast China, 7501350," Journal of the Economic and Social History of the Orient 10.1 (1967), 102-59.

${ }^{2}$ William Guanglin Liu, "Shichang, zhanzheng he caizheng guojia: dui Nansong fushui wenti de zaisikao" 市場、戰爭和財政國家一对南宋賦稅問題的再思考, Taida lishi xuebao 臺大歷史學報 42 (Dec. 2008), 221-85, and "The Making of a Fiscal State in Song China, 960-1279," Economic History Review 68.11 (Feb. 2014), 48-78.
} 
At the same time, the Song government had several military failures (real or perceived) that later historians used to characterize the dynasty as fundamentally weak. The usual contrast presented is between the Song's strong civil culture, particularly during the brilliant eleventh century, and its military defeats. A natural link has been assumed between the political and cultural dominance of civil officials and military failure. $^{3}$ By contrast, the Song's two major antagonists, the Kitan Liao dynasty and the Jurchen Jin dynasty, were ruled by vigorous and militarily powerful steppe peoples. The Song in this view was always militarily inferior to the Liao and Jin. Song institutions and culture were, by extension, implicated in these battlefield results. The kernel of truth in these assumptions masks a vast misinterpretation of the drivers of Song history. Even the most obvious points of comparison, that the Song ruled a far more populous and wealthy empire for far longer than either the Liao or Jin dynasties, usually goes unremarked.

The Song dynasty was extremely successful by almost every social, cultural, technological, economic and even military standard for a pre-twentieth-century state. The Song's greatest military failure has ultimately been historiographical, rather than real. Clear military failures have been amplified and decontextualized to support a more dramatic historical narrative. Some of the historiographical issues began in the eleventh century as part of political struggles within the Song government. ${ }^{4}$ This institutional struggle was fought on many levels. Over time members of the literati class on all sides of the political struggle developed a shared ideological position regarding the military. The authors of all of the records we rely upon for Song history came from that class and consequently held their values.

More significantly from the perspective of institutional history, three hundred years of changing institutions have been compressed into a monolithic and constant morality tale. ${ }^{5}$ Yet Song institutions, particularly military institutions, were not constant. The split of the Song into the Northern Song (960-1127) and the Southern Song (11271279), following the fall of North China to the Jurchen Jin in 1127, marked an enormous institutional shift in government and military administration. The Southern Song confronted entirely different military problems and its army and navy developed out of a different history from that of the Northern Song. Consequently, the Southern Song army and navy were very different institutions than their Northern Song progenitors.

\footnotetext{
3"Song emperors deliberately strengthened the civil principle (wen) over the military principle (wu)." Dieter Kuhn, The Age of Confucian Rule: The Song Transformation of China (Cambridge, Mass.: Harvard University Press, 2011), 2.

${ }^{4}$ Charles Hartman, "Chinese Historiography in the Age of Maturity," in The Oxford History of Historical Writing, edited by Sarah Foot and Chase F. Robinson (Oxford: Oxford University Press, 2012), 44-49, on Ouyang Xiu and Sima Guang's influence on historiography in the $11^{\text {th }}$ century and the influence of a relatively small number of high-ranking literati officials in recasting earlier Chinese history.

${ }^{5}$ Paul Smith, "Introduction: The Sung Dynasty and its Precursors," in The Cambridge History of China: Volume 5, Part One, The Sung Dynasty and its Precursors, 907-1279, edited by Denis Twitchett and Paul Smith (Cambridge: Cambridge University Press, 2009), 12: “T' ai-tsu's choice of centralized control over military autonomy—often described by the phrase 'emphasizing the civil and deemphasizing the military' (ch'ung [sic]-wen ch'ing-wu)—is sometimes indicted as a source of the Sung's putative military weakness." Kuhn, The Age of Confucian Rule, 4: "If the Song dynasty reaped unprecedented benefits from the flowering of civil society, it also paid a price for its military shortcomings."
} 
Institutional history writing has long been a particular Chinese strength, and Song military institutions have been studied in great depth. ${ }^{6}$ Here I provide an overview with some illustrative details to develop two points. First, the separation, delineation, and expansion of the military side of government both reflected and caused the growing power and influence of the military and martial culture during the Song. This development has previously been erroneously used to argue for the subordination of the military and the rise of civil power and culture. Second, the institutional history of the Song military is an integral part of Song history just as the Song military is part of Song culture. Military culture was probably far more important in the lives of commoners than Confucian or literati civil culture, because it affected more people in their daily lives. Furthermore, the military itself was by far the largest part of government manpower.

\section{CORE MILITAR Y INSTITUTIONS}

To the extent that institutional design instantiates cultural and political values, those institutions demonstrate the designers' values. In the case of the Song, however, there was a significant gap between what the court needed its institutions to do and what emperors, statesmen, and historians often wished those institutions could do. The dynasty inherited military institutions designed for conquest and transformed them into the tools of an established empire. Northern and Southern Song military institutions were designed for defense and internal security. They therefore required extra preparation to become effective for offensive or expansionary actions. Defensive success is far less glorious than offensive success, and the Song struggled against a series of powerful foes. It ultimately fell to the Mongols after half a century of successful defense.

At several points the Song court did shift to an offensive stance. Song armies attacked the Tanguts in the late eleventh century, followed by failed attempts to capture the Sixteen Prefectures from the Liao in the early twelfth century. The Southern Song launched several failed offensives to recapture the north. The Tangut campaign achieved some success, as did some of the Southern Song offensives, demonstrating that a Song court run almost exclusively by literati officials was prepared to go to war. War was waged based upon raison d'état (as understood by a given emperor and his officials);

\footnotetext{
${ }^{6}$ Peter Lorge, "Institutional Histories," in The Oxford History of Historical Writing (400-1400), Vol. 2, edited by Sarah Foote and Chase Robinson (Oxford: Oxford University Press, 2012), 476-95. For Song military institutions, see Chen Feng 陳峰, Songdai junzheng yanjiu 宋代軍政研究 (Beijing: Zhongguo Shehui Kexue Chubanshe, 2010); Chen Feng, Wushi de Beiai: Beisong chongwen yiwu xianxiang yanjiu 武士的悲哀: 北宋崇 文抑武现象研究 (Beijing: Renmin chubanshe, 2011); Wang Zengyu 王曾瑜, Songchao Bingzhi Chutan 宋朝 兵制初探 (Beijing: Zhonghua Shuju, 1983); Michael McGrath, "Military and Regional Administration in Northern Sung China (960-1126)," (Ph.D. diss., Princeton University, 1982); John Richard Labadie, "Rulers and Soldiers: Perception and Management of the Military in Northern Sung China (960-ca. 1060)," (Ph.D. diss., University of Washington, 1981); Winston Lo, An Introduction to the Civil Service of Sung China (Honolulu: University of Hawaii Press, 1987); Edmund Worthy, "The Founding of Sung China, 950-1000: Integrative Changes in Military and Political Institutions," (Ph.D. diss., Princeton University, 1976); Liang Tianxi 梁天錫, Song shumiyuan zhidu 宋樞密院制度 (Taibei: Liming Wenhua Shiye Gufen Yuxian Gongsi, 1981); Elad Alyagon, "Inked: Song Soldiers, Military Tattoos and the Remaking of the Chinese Lower Class, 960-1279," (Ph.D. diss., University of California, Davis, 2016); Fan Xuehui 范學輝 Songdai sanya guanjun zhidu yanjiu 宋代三衙管軍制度研究 (Beijing: Zhonghua Shuju, 2015)
} 
literati officials and emperors were no more or less inclined toward war and no more or less capable in carrying it out than their military counterparts. ${ }^{7}$

The analysis provided here is biased toward the Northern Song, particularly the early Northern Song. Partly this is because several of the most important sources on the Song like Li Tao's 李壽 (1115-84) Xu Zizhi tongjian changbian 續資治通鑑長編 (Long Draft of "A Continuation of the 'Comprehensive Mirror to Aid in Government") were compiled in the Southern Song and provide better coverage of the Northern Song. ${ }^{8}$ More significantly, many works composed during the Song or shortly thereafter (e.g. Ma Duanlin's 馬端臨 [1245-1322] institutional history Wenxian tongkao 文獻通考) assumed that the Song founders instituted policies instantiated through dynastic institutions that characterized the entire dynasty. Founding policies made the dynasty what it was, making the institutional arrangements of the early dynasty particularly important. This bias has shaped much subsequent scholarship up to the present and an authoritative, "objective" account is impossible. The reality was complicated, institutional changes were often organic, and changing circumstances could be as important as planned reforms. ${ }^{9}$

\section{PROFESSIONAL SOLDIERS}

Three distinct aspects of Song military institutions persisted through the entire dynasty. First, the imperial army employed professional soldiers. Paid by the central government, both officers and rank-and-file soldiers officially had no other means of supporting themselves other than army service. These imperial soldiers were distinct from the militia, who served at the lowest level of armed service. Farming most of the time and of limited military value, militiamen were not professionals. This army was not only separated into three tiers, imperial army, provincial armies, and militias (as well as non-Chinese auxiliary forces on the border), but also divided at the top with the imperial army separately organized into Imperial Guard (Shiwei majun bujun 侍衛馬軍步軍) and Palace Corps (Dianqian mabu jun 殿前馬 步軍). This neat structure functioned only during the Northern Song period. During the Southern Song period, most of this organization collapsed and was patched together into a complex and unstable structure.

The old units of the Song imperial army were reduced to provincial forces and new armies created in the chaos after the fall of the north. Just as critically, change was driven by the navy's unprecedented significance to the empire's defense. This would have made sense to the Southern Tang regime from the tenth century, one of the states the Song conquered in recreating the Tang empire, but no other major Chinese dynasty had ever relied upon a navy for its defense. In all of this the Song army continued to rely upon paid, professional soldiers for its real fighting force.

\footnotetext{
${ }^{7}$ Peter Lorge, "Introduction," in Debating War in Chinese History, edited by Peter Lorge (Leiden: Brill, 2013), 1-10.

${ }^{8} \mathrm{Li}$ Tao actually served in the Ministry of War, and later as a Military Intendant.

${ }^{9}$ Kuhn, The Age of Confucian Rule, 2: "Aspiring to establish a long-lasting dynasty, these three model emperors [Taizu, Taizong, and Zhenzong, the first three Song emperors] understood that they must create precedents suitable not just for themselves but for their successors."
} 
Not only the Song imperial armies but also the provincial armies were professional forces made up of government paid, trained and equipped soldiers. Only the local militia approached the Chinese ideal of the farmer-soldier. The employment of professional soldiers grew out of the late Tang dynasty shift to this military practice. It was one of the most marked and important aspects of Song military institutions. The Song dynasty maintained an immense standing army throughout its entire history. Where the Northern Song kept at least half of the imperial army in the capital Kaifeng to protect the court from mutiny, the Southern Song was forced to return to the Tang practice of posting the majority of its strongest forces on the border.

\section{BUREAU OF MILITARY AFFAIRS}

The second distinct aspect of Song military institutions was the prominence in the government of the Shumiyuan 樞密院 or Bureau of Military Affairs, as it can best be described during the Song. Whereas earlier dynasties relied more heavily on the Ministry of War (Bingbu 兵部), one of the six ministries under the Department of State Affairs (Shangshu sheng 尚書省), the Song military bureaucracy was a larger, far more developed, and more separate entity. The Ministry of War did remain within the civil bureaucracy of the Secretariat-Chancellery (which the Department of State Affairs was still part of), though with very limited responsibilities. War and the military were so important during the Song that the military bureaucracy (as distinct from the army bureaucracy) had to be separate from the civil bureaucracy in order to prevent any single official from gaining undue power or influence at court. The emphasis on centralization of powers had to be balanced by careful separations within the imperial government. Officials in charge of military matters were part of a different structure than those charged with civil matters. Only the emperor united the two parts, though he did, at times, also allow the highest officials of the civil bureaucracy to contribute to military decisions. Conversely, military officials were ubiquitous in the Song government. ${ }^{10}$

During the Southern Song the Bureau continued to function in a similar bureaucratic way, but with significantly diminished powers. Powerful military officials based on the border dealt with the most pressing military border problems. The court decided general military policy, but the imperial government had direct control of fewer troops. A sign of how much less important the Bureau became was that when the emperor wanted to decrease the power of several of the generals who had saved the dynasty in the aftermath of the fall of the north, those generals, Zhang Jun 張俊 (1086-1154), Han Shizhong 韓世 忠 (1089-1151), and Yue Fei 岳飛 (1103-42), were promoted into the Bureau, cutting their ties to their troops. The history of the Bureau during the Song was both a sign of the military's importance and the development of military affairs as a separate area of government administration. This change from earlier practice was an organic evolution from the Tang dynasty through the five dynasties of the Five Dynasties and Ten Kingdoms period and an intentional effort to respond to the greater need for specialization in

\footnotetext{
${ }^{10}$ McGrath, "Military and Regional Administration in Northern Sung China (960-1126)," 246: "For all its civilian values, the Sung state was powerfully formed by dynastic and imperial requirements, and it was pervaded with military officials operating at all levels of government."
} 
administration. The various discussions of the new importance of the Bureau and its relationship to the rest of the government cited below demonstrate that contemporaries were aware of a significant institutional change.

\section{MILITARY AND MARTIAL CULTURE}

Third, military and martial culture developed tremendously during the Song. Within the army and the military bureaucracy this was caused by the military's professionalization, though the development of martial culture during the Song was a much broader phenomenon. ${ }^{11}$ For the government this had two aspects, soldiers' professionalization and the military bureaucracy's professionalization. Professionalization refers here to specialization (expertise) coupled with a fairly narrow career path. For example, Robert Hartwell has shown that there was a clear career path for finance experts in the Song bureaucracy. ${ }^{12}$ We know about such a career path because some of the literati officials on that path passed the civil service exams and attained a sufficiently high rank to show up in historical sources. The same is not true for military bureaucrats working in the Bureau of Military Affairs. None of the high-ranking officials that we know of who ran the Bureau came up through the lower ranks of the Bureau. All of them were either civil officials or generals who had earned their position on the battlefield.

The military bureaucracy was staffed by officials and functionaries from a much more diverse background than the civil bureaucracy. Although the civil bureaucracy increasingly was staffed by men with civil examination degrees,${ }^{13}$ the Bureau had civil examination graduates, military examination graduates (starting in the late Northern Song), former army officers, and literate clerks. Except for a few high-ranking generals, the highest levels of the Bureau were usually high-ranking civil literati with jinshi degrees. ${ }^{14}$ My category of literati military bureaucrats includes men of literati background who served in the Bureau with or without a civil examination degree and held a military prestige title or status. ${ }^{15}$ During the Southern Song, a good argument could be made for also including in the category men of literati background who either passed the military exams or went through the imperial academy in the Southern Song. These men straddled two cultural worlds, though we

\footnotetext{
${ }^{11} \mathrm{~A}$ good example of the development of Song martial culture is the creation of the fictional Shuihuzhuan stories; see Paul Smith, "Shuihu zhuan and the Military Subculture of the Northern Song, 960-1127," Harvard Journal of Asiatic Studies 66.2 (December 2006), 363-422.

${ }^{12}$ Robert Hartwell, "Financial Expertise, Examinations, and the Formulation of Economic Policy in Northern Sung China," Journal of Asian Studies 39 (1971), 281-314. The military bureaucracy maintained a separate rank system from the civil bureaucracy, making movement between the two difficult, but not impossible.

${ }^{13} \mathrm{By}$ the eleventh century, these were virtually exclusively jinshi degrees in the case of those "within the stream." Those "within the stream" (liunei 流內) were ranked officials who had status in the bureaucracy of officials. Those "outside the stream" (liuwai 流外) were sub-official functionaries without official rank or status in the bureaucracy of officials.

${ }^{14}$ Liang Tianxi, Song shumiyuan zhidu, 12-13, charts the percentage of civil officials serving as Commissioner or Assistant Commissioner of the Bureau: Taizu 40\%, Taizong 60\%, Zhenzong 66\%, Renzong 79\%, Yingzong 92\%, Shenzong 93\%, Zhezong 100\%, Huizong 92\%, Qinzong 92\%, Gaozong 96\%, Xiaozong $96 \%$. Every emperor after Xiaozong until the end of the dynasty used $100 \%$ civil officials. For all eighteen emperors $91 \%$ of Commissioners or Assistant Commissioners of the Bureau were civil officials.

${ }^{15}$ Most officials who entered the government through yin privilege received military prestige titles, thus preserving the status of civil titles.
} 
have very little information on them. Like the lower and middle ranks of the civil bureaucracy, most government officials remain anonymous to history.

Furthering a process that had begun during the Tang period, the military became a separate profession in the Song. Hundreds of thousands of soldiers were based in the capital during the Northern Song, when martial culture, just like civil culture, developed rapidly. In the Northern Song capital, at least, about half of the imperial army soldiers lived in proximity to the civilian and ruling population. During the Southern Song, however, most of the dynasty's real military units were completely separated from civilian centers. In the Southern Song the main armies were on the northern border. The institutional structure of the Song army and its civil-military connections produced a fully developed martial culture when the strongest military units became not only culturally, but also physically separated, from the centers of civil culture.

The final aspect of Song institutions driving changes in military culture also took place in the Southern Song. During the Northern Song period, many literati denigrated and suppressed the military, but in the Southern Song the status of soldiers rebounded. Desperate for soldiers, the Southern Song government treated new recruits better. Government institutional needs trumped literati ideology, even as many literati continued to look down upon the military and military culture. Southern Song literati attitudes toward the military became separated from the government's institutional position, and likely more general attitudes in society as well. The military gained in status at all levels, because they were needed. This change throws into relief the military's poor status during the eleventh century. Literati ideology could drive government policies, because the empire did not face any existential threats. It was lack of war rather than civil ideology that kept literati officials in control. North China fell to the Jurchens, because more than a century of peace had left the Song unprepared for an existential threat. Military influence declined and civil influence increased when military affairs were relatively minor border problems.

\section{HISTORICAL LEGACIES AND SONG CENTRALIZATION}

The long-standing stereotype about Song military weakness conflates many complex factors into a simple moral tale told through the lens of institutional history. Since, by definition, all Chinese dynasties are created and destroyed through military action, the beginning and end of dynasties are played out on the battlefield. Chinese historians, all of them literati and most having served as civil officials, assumed and asserted basic moral failings of professional soldiers and generals. Elad Alyagon has summed up Song literati attitudes: "Soldiers were a savage, lazy, criminal lot."16

If the nature of soldiers was a constant, it would follow that the dynasty's fate was decided by the actions of the literati class, who filled the ranks of the Song government, usually after having passed civil service exams. Officials drawn from the literati class shared a common literate culture that prized education and intellectual attainment over physical skills. That education also assumed a commensurate moral development unattainable outside of a formal textual training. When the literati failed in their moral

\footnotetext{
${ }^{16}$ Alyagon, "Inked," 22.
} 
responsibilities, they opened the door for chaos. Ouyang Xiu 歐陽修 (1007-72) famously wrote that the rise and fall of dynasties during the Five Dynasties Period was all due to soldiers. ${ }^{17}$ But Ouyang's point had two sides: soldiers caused the problems of chaos, but they were able to do so only because literati failed to exert their proper moral authority.

Deep fears of military (and eunuch) power were therefore embedded in the foundation of Song institutional culture. However, neither the military nor the eunuchs could be entirely dispensed with or controlled. Although broader historical legacies influenced Song military institutions, the deep-seated contempt of Song civil elites likely bore some responsibility for undermining the Song army's effectiveness. Still, it was the absence of direct threats that made this ideology possible. Song literati did not just express contempt for soldiers, they institutionally enacted that contempt, forming what Elad Alyagon calls a penal-military complex in the Northern Song. ${ }^{18}$ These attitudes were based in a specific history.

Song institutions in general grew out of Tang dynasty and Five Dynasties precedents. They developed organically in response to the turbulent history of ninth- and tenthcentury China rather than beginning de novo with a "rational" plan of organization. Consequently, titles, positions, ranks, and pay grades were complex and hard to reconcile at the founding of the dynasty and only grew more complicated as customs and practices evolved over the dynasty's course. The army and the military bureaucracy were completely entangled in this complex system to which were added the additional concerns of military effectiveness and loyalty. Both military effectiveness and loyalty, measured in battlefield successes, failures, and mutinies was perhaps easier to measure than civil administrative or policy competence.

From a purely institutional perspective, the government of the Song dynasty was highly militarized. The government was split between the civil part and the military part, with a financial section varying in its identification, independence, and authority over time. In addition to the military bureaucracy, there was the army itself (which also included a riverine navy). As in most centralized bureaucratic states, the military budget was the largest component of the Song government budget. ${ }^{19}$ The central government recruited, trained, equipped, and paid imperial armies. Less clear are the origins of the common soldiers and the officers. Beginning in the eleventh century, the state implemented a military exam system, but its recruitment value was limited.

\footnotetext{
${ }^{17}$ Ouyang Xiu 歐陽修, Xin Wudai shi 新五代史 (Beijing: Zhonghua Shuju, 1995), 27.297.

${ }^{18}$ Alyagon, "Inked."

${ }^{19}$ Hon-chiu Wong, "Government Expenditures in Northern Sung China (960-1127)" (Ph.D. diss., University of Pennsylvania, 1975), 60-61, estimated the military costs were about 70\% of the regular government budget, exclusive of the extra costs of individual campaigns; Walter Scheidel, "The Early Roman Monarchy," in Fiscal Regimes and the Political Economy of Premodern States, edited by Andrew Monson and Walter Scheidel (Cambridge: Cambridge University Press, 2015), 242, regarding government expenditure: "The key item was military spending"; John Haldon, "Late Rome, Byzantium, Early Medieval Western Europe," in Fiscal Regimes, ed. Monson and Scheidel, 363-64, with respect to Byzantine Empire: "There is no doubt that, for much of the period between the reigns of Justin II and Basil II (565-1025), the army and related military costs swallowed up the largest part of the state's annual income in one form or another, at an absolute minimum some 35 percent- probably much more-in the sixth century, and an even greater proportion in the reduced circumstances of the seventh and eighth centuries."
} 
The root policy of the Song dynasty was not demilitarization but rather centralization (“strengthening the trunk and weakening the branches" [qianggan ruozhi 強幹弱枝]). ${ }^{20}$ Centralization simultaneously increased the militarization of the imperial government while diminishing the military power of regional commanders, including generals on the border. The structure of the Song government stemmed from that of the Military Governors (jiedu shi 節度使), who had been regional power holders in the Tang and Five Dynasties and Ten Kingdoms periods. ${ }^{21}$ These governors unified political and military power in their territories, nominally, in their original form, in service to the central government. Their relative autonomy and control over local resources allowed them to defend the empire effectively. Military Governors arose as local expedients on the border, and were effective for a time in ameliorating border problems.

As the scale of border problems increased, and Military Governors therefore required greater resources and autonomy to respond to them, the political reliability of the governors also became a high-stakes problem. Any move by the court to restrict a Military Governor would be seen as of lack of trust. A breakdown in relations between the court and a Military Governor could be disastrous, as demonstrated by the enormously destructive An Lushan Rebellion (755-63), which is discussed in David Graff's essay elsewhere in this special issue. The Song response, or more properly the institutional response that developed in North China during the Five Dynasties, was a central court that controlled all political and military power within its territory.

\section{RETHINKING IDENTITY AND CIVIL DOMINANCE}

The issue of civil dominance of the Song military has two main historiographical components: the belief that civil dominance was a basic Song policy and the belief that civil dominance resulted in poor military performance. Recent scholarship has largely abandoned the idea "Emphasize the civil, de-emphasize the military" (zhongwen qingwu 重文輕武) as basic Song policy. ${ }^{22}$ The hoary stereotype that civil dominance resulted

\footnotetext{
${ }^{20}$ The first mention of that specific policy was during Song Taizong's reign. Li Tao 李壽, Xu zizhi tongjian changbian 續資治通鑑長編 (Beijing: Zhonghua Shuju, 2004), 40.844. See also 47.1037, which uses the variant "strengthen the trunk and weaken the branches" (qianggan ruozhi 僵幹弱枝) during Zhenzong's reign, and 133.3178, for its use during Renzong's reign. In other contexts it is much more clearly focused on maintaining a powerful central army around the person of the emperor, Toqto'a 脫脫, Songshi 宋史 (Beijing: Zhonghua Shuju, 1990), 293.9798 and 374.11590, which specifically connects it to the "ancestral laws." Wang Yucheng 王禹偁 (954-1001) once proposed "restraining civil officials and energizing military officers" (yiwenshi yi juwufu 抑文士以激武夫); Toqto'a, Songshi 293.9793.

${ }^{21}$ Wang Gungwu, The Structure of Power in North China During the Five Dynasties (Kula Lumpur: University of Malaya Press, 1963).

${ }^{22}$ The first modern description of basic Song policy as "Emphasize the civil, de-emphasize the military" was by Fang Hao, Songshi 宋史 (Taibei: Zhonghua Wenhua Chuban Shiye Weiyuan Hui, 1954), 66. The earliest premodern description was in the Ming dynasty novel Erke Paian Dunqi 二刻拍案. See Peter Lorge, “The Northern Song Military Aristocracy and the Royal Family," War and Society 18.2 (2000), 37-47. The closest Song dynasty use of those terms was by Fu Bi 富㢱 (1004-83), "Shang Renzong lun wuju wuxue" 上仁宗論武舉武學, in Zhao Ruyu 趙汝愚, Songchao Zhuchen Zouyi 宋朝諸臣奏議 (Shanghai: Shanghai Guji Chubanshe, 1999), 892, where he lamented in the 1030s that everyone had turned toward civil pursuits and away from studying war. If the Cambridge History of China is any measure, "Emphasize the civil, deemphasize the military" is no longer considered a Song policy since it does not show up anywhere in the
} 
in poor military performance has never been convincingly demonstrated because officials' backgrounds are poor indicators of their policy orientations. One cannot determine an official's background by looking at the military strategy or policy he recommended. Military men were not consistently more bellicose than literati. An official's hometown is often a far more accurate predictor of hawkish or dovish recommendations. ${ }^{23}$

Chen Feng proposes a more accurate characterization of Song policy, "Emphasize the civil, Restrain the military/martial” (chongwen yiwu 崇文抑武). ${ }^{24}$ The early Song dynasty tried to remove military men from government's upper reaches, because they were seen as a threat to the polity's survival. Highly educated men who had not served in the military subsequently replaced them. Within the army leadership itself, top command positions were left vacant to prevent any individual from unifying control over the dynasty's armed forces. ${ }^{25}$ Finally, border commanders who held both civil and military power were gradually removed from power. This institutional process coincided with the establishment of the dynasty and the conquest of most of China.

The disappearance or removal of military men from officialdom in the Northern Song, which a number of statesmen lamented, was partly due to fears of the military, partly due to an increasing number of exam graduates vying for government positions, and also partly due to the inability of civil culture fully to subsume military culture under civil culture. Civil officials believed that they should dominate by virtue of their civil accomplishments and culture. Even though the emphasis on civil education and civil degrees placed military men at a disadvantage in the bureaucracy, they did not always accept civil values. ${ }^{26}$ Some military men, like Di Qing 狄青 (1008-57), pursued some level of literate education during their military careers. Whether this was done out of interest in literate culture or from a calculation of bureaucratic advantage is unclear. Fan Zhongyan 范仲淹 (989-1052), General Di's patron, certainly felt that it was a genuine pursuit of literate education. Yet General Di may well have been the exception since we have no other similar example. The sources do not allow us to quantify military attitudes toward civil officials. To be fair to Song government officials who felt educated civil officials were best suited to serve in government, a peacetime bureaucracy required more literate bureaucrats than battlefield warriors.

\footnotetext{
Song volume. See Denis Twitchett and Paul Smith, eds., The Cambridge History of China, Volume 5, Part One, The Sung Dynasty and Its Precursors.

${ }^{23}$ Huang K'uan-ch'ung, “Cong hezhan dao nanbeiren” 從和戰到南北人, in Zhongguo lishishang de fenyu he xueshu yantao hui lunwen ji 歷史上的中國歷史上的分與合 學術研討會論文集 (Taibei: Lianhe baixi wenhua jijinhui, 1995), 169-89.

${ }^{24}$ Chen Feng, Songdai junzheng yanjiu, 2-3, and more extensively, Chen Feng, Wushi de Beiai.

${ }^{25}$ Worthy, "The Founding," 167.

${ }^{26}$ Two examples of military men disparaging civil officials, one in the early Northern Song and one during the Southern Song, are illustrative. In 1004, General Gao Qiong was insulted by a civil official when emperor Zhenzong was confronting the Liao army at Chanyuan. Gao pointed out that he had attained his position by fighting, and suggested that the official read a poem to make the enemy go away. Li, Xu zizhi tongjian changbian, 58.1287. During the Southern Song, Lü Wende 呂文德 (d. 1269), a key border commander with a reputation for respecting civil officials, privately disparaged them: "I always disregard literati, because they are not able to handle any substantial affairs," Toqto'a, Songshi 450.13258, cited in Fang Zheng-Hua, "Military Families and the Southern Song Court," The Journal of Song-Yuan Studies 33 (2003), 57.
} 
Song court culture was more civil-oriented than Tang court culture, though during the Tang the civil-military split was sometimes ethnically tinged as a Chinese-Türkic split. Where the Song civil-dominance paradigm falters is in the certainty that the court culture of the civil elites was broadly shared within the government and society. The great Confucian thinkers of the eleventh century who laid the foundations for Zhu Xi's synthesis in the twelfth century were aroused to argue for their vision of a Confucian government and society as reaction against the reality of their times. Moreover, their focus was always on their own class, believing unquestionably in the power of cultivated men to sway the rest of society. Such arguments would hardly have been necessary if Song society already conformed to their vision. Indeed, their arguments clearly show that their views were not even shared by the men of their own class. Zhu Xi and his supporters fought a lengthy campaign to impose their views on the literati class in the face of strong and continuous resistance. ${ }^{27}$

It is difficult to describe the segmentation of Song culture and society. The literati, that single, self-conscious class of educated men who, despite their internal differences, shared a broad cultural perspective, wrote or compiled almost all of our sources. From the civil literati perspective, the ideal military man would be effective, loyal, and willingly submissive to the civil elite. Military men would have to accept that they were socially and intellectually inferior to educated men. Yet we have little evidence that effective, loyal military men regarded themselves as inferior to civil officials; indeed, they were often contemptuous of civil officials, as the example of Lü Wende 呂文德 (d. 1269) demonstrates. Lü was wise enough to flatter literati, openly show deference, and reserve his contempt for private comments because he knew that overt signs of disrespect for civil officials could get generals killed. ${ }^{28}$ We have no evidence that military men shared literati views of the relative value of military and civil men. The value of education in wartime was not obvious, and might appear, in fact, to undermine military effectiveness.

The best indicator of the military's importance in government and society was war or peace. While the institutional structure tried to protect the dynasty from military subversion, the need for soldiers waxed and waned due to factors often outside the court's control. Part of the restraint on Song military policy, something true of other dynasties as well, was that aggressive military action increased the power of military men at court. Hence the rise of civil political power at the beginning of the Song was due to internal security concerns and the end of war in 1005. The irruption of war with the Tanguts in 1038 only temporarily raised the prospects of military men because the war was effectively concluded by 1042 . On the strategic level, the only Song objective was to defeat the Tangut invasion and reestablish a peaceful border with a minimum of concessions. In sharp contrast, from the later eleventh century, campaigns aimed to destroy the Tangut state. ${ }^{29}$ Civil officials did not want a broader conflict that would have increased

\footnotetext{
${ }^{27}$ Frederick Mote, Imperial China, 900-1800 (Cambridge, Mass.: Harvard University Press, 1999), 316-17.

${ }^{28}$ Fang Zheng-Hua, "Military Families and the Southern Song Court," 57.

${ }^{29}$ For the first Tangut campaigns see Michael McGrath, "The Reign of Jen-tsung (1022-63) and Ying-tsung (1063-67)," in The Cambridge History of China, Volume 5, Part One, The Sung Dynasty and its Precursors, edited by Denis Twitchett and Paul Smith, 300-316; for the second Tangut campaign see Paul Smith, "Shentsung's Reign and the New Policies of Wang An-shih, 1067-1083," in the same volume, 464-78.
} 
the power of the military or unleashed political instability. War had raised the value of the military and disrupted the political balance of power. Once the war was over, the political reforms briefly introduced in response were reversed.

That desultory four-year war on the border never posed an existential threat to the dynasty, but it was important for almost producing institutional reform within the broader Song government. Not until the landmark New Policies (Xinfa 新法) would government be significantly reformed. A key objective of the New Policies was to strengthen government finances to increase military power to defeat the Tanguts and the Liao. The excuse of war was really the only way to convince the emperor to give one side greater political power. Thus, literati officials used military policy for internal and external reasons. The clear political value of a belligerent military policy belies the idea that civil values were dominant. Civil policy was not in and of itself a politically viable means for gaining power within the government. Song emperors needed the army to defend the empire and preserve their rule, but they wanted it to win them military glory in successful offensive campaigns again the Tanguts and Liao. It was the possibility of changing the army to make it do what Shenzong wanted it to do rather than just what he needed it to do that made the New Policies attractive.

Civil dominance is therefore a tendentious characterization. Civil officials believed that they should have the final word on government, society and culture, but the emperor, not the civil officials, decided policy. Civil officials consistently emphasized the civil aspects of imperial rulership, but emperors themselves were ritually and institutionally constructed as balanced civil and military men. Civil officials preferred to see the emperor as a civil-oriented man much like themselves. This was easy to do for palaceborn emperors who were mostly educated in the same way that civil officials were. These emperors were literate, but their legitimacy and that of their dynasty rested on the original military conquest. ${ }^{30}$ Literati officials worked assiduously and with some success to draw a cloak of ritual and civil cultural legitimacy over that naked military requirement.

Imperial authority rested on the army. The dynasty relied upon military institutions for its existence and invested commensurate attention in those bureaucratic and operational structures. That reality may have been distasteful to many literati, but the senior officials in the government all understood it to be true.

\section{CHANGE IN SONG MILITARY INSTITUTIONS}

The following two sections provide an institutional history of the Bureau of Military Affairs and the Song army. These institutions changed significantly over the Song dynasty in response to both internal political concerns and external forces. Previous scholarship emphasized the aspects of those institutions and their changes that increased, or at least appeared to increase, civil control over the military, and implicitly accepted that the effectiveness of the military was primarily a function of those institutions.

\footnotetext{
${ }^{30}$ Literate military men were rare enough to be noteworthy, see for example Song Zhenzong's praise of He Chengju 何承矩 (946-1006), as “literate with a good reputation" (zhishu haoming 知書好名). Li, Xu zizhi tongjian changbian, 58.1273.
} 
That same scholarship also assumed that those changes were driven by a unified, static civil culture which seamlessly included all literati inside and outside of government. But institutional change moved both ways, for and against greater civil, or more usually centralized, control. Some changes were temporary expedients, others may not have served their intended purpose, and very few were part of a carefully worked out plan like the New Policies. The ebb and flow of the institutional changes show by themselves that if its military institutions were a reflection of Song dynasty civil culture, that culture was inconsistent, contradictory, and deeply confused. It is more likely that the complexity of the changes, and their significant differences across the dynasty, reflect a diverse civil and military culture within the government and society.

Northern Song institutions were scarcely comparable to Southern Song institutions, because external factors forced dramatic changes at every level. Literati culture may have appeared roughly consistent at some level with respect to war, peace, and border affairs over the course of both the Northern and Southern Song, but the government, as distinct from literati culture, had to respond to shifting internal and external threats. ${ }^{31}$ In fact, even literati views of war and peace were not monolithic. Although emperors and their ministers wished they could somehow create a strong, loyal and cheap army, they were never able to square that circle. It was simply impossible. At best, the army was episodically strong and loyal, but at a tremendous cost in men and material. Even if the expenses had been sustainable, the Song military bureaucracy and the army would have struggled to maintain effectiveness during periods of peace. The bureaucracy failed even to recruit enough soldiers, let alone preserve military skills as veteran soldiers and officers retired.

The army itself, which was overseen by the Bureau of Military Affairs, was a highly segmented institution, divided both horizontally and vertically for reasons of internal security, economy, regional power balance, and border defense. In addition to the two separate imperial standing forces, the Palace Corps and the Imperial Guard, which were themselves also divided into infantry and cavalry commands, there were also provincial forces, local militias, and non-Han border forces. Military forces at many levels also carried out police and labor duties at various times. To complicate matters even further, the army changed significantly from its founding institutions at least twice, some attempted reforms like those under Emperor Shenzong's New Policies were only partially and temporarily instituted, and the connection between names and functions was very unstable, particularly during the Southern Song. ${ }^{32}$ As a consequence of this, the tactics and force structures of the army were similarly volatile and are not well described in the extant sources.

The history of the Bureau of Military Affairs and its growth into half of the regular government bureaucracy is one of the strongest arguments for the importance of military

\footnotetext{
${ }^{31}$ On the issues of the war and peace parties, as represented in the Reform and Conservative factions, see Mote, Imperial China, 135-44 and 112-18.

${ }^{32}$ Here I follow Fang Cheng-hua's point that the New Policies should be attributed to Emperor Shenzong rather than his Chief Minister Wang Anshi, as has previously been common practice. Fang Cheng-hua 方震 華, “Chuantong lingyu ruhe fazhan” 傳統領域如何發展, Taida lishi xuebao 臺大歷史學報 48 (2011), 169. The attribution of policies to Chief Ministers or other officials is an example of the literati-centered history writing common to Song historiography.
} 
power to the state during the Song. The Bureau began as a eunuch office for secret affairs under the Tang dynasty. Five Dynasties rulers replaced the eunuchs with their own loyalists in the same manner that they placed their own loyalists in charge of the organs of the central government and sent out men to control regional offices. The earliest manifestation of the Shumiyuan was quite different from the Bureau of Military Affairs that it became in the Song. Its creation and evolution during the Tang dynasty was intimately connected to the virtually simultaneous creation of the palace armies that became the Song imperial armies. In that sense, as with so many other aspects of Song culture, practices that began in the Tang reached full maturity only in the Song. It lost most of its real power during the Southern Song.

\section{TANG GENESIS OF THE BUREAU OF MILITARY AFFAIRS}

The Shumiyuan began as an inner palace office staffed by eunuchs, the main servitors of the emperor within the inner palace. Eunuch power increased considerably in the late Tang dynasty as the emperors struggled to gain more direct control over the empire. Tang emperors created both the Shumiyuan and the palace armies with eunuchs in control to increase imperial power over that of court officials, generals, and Military Governors, who had come to expect significant levels of autonomy from the state. As instruments of centralized power it is not surprising that these institutions continued into the Song. Where late Tang emperors most trusted the eunuchs, Five Dynasties emperors relied upon military men, and Song emperors found civil officials to be the most politically reliable. Seen from this perspective, the relentless efforts of civil officials in the Song to denigrate military men and insist on a civil orientation in imperial education was intended to discredit potential political rivals who had in recent memory been the emperor's men. These efforts extended into the writing of history beginning in the eleventh century and continuing into the thirteenth century.

The eunuch Li Fuguo 李輔國 (704-62) was appointed Chief of Staff of the Command Headquarters between 756 and 762 to coordinate Emperor Suzong's response to the An Lushan Rebellion. ${ }^{33}$ This headquarters combined civil and military authority, including direct command of field armies. It was also the direct conduit for communication to and from the emperor. This latter function was the true root of what would become the Shumiyuan and its eunuch functionaries' source of power. Li Fuguo's immediate successors were less powerful than he was, but they retained informal influence. ${ }^{34}$ Tang emperors began to consult with these eunuchs on policies and the appointment of high officials. This was a function of the emperors' perception of their loyalty rather than a formal structure of the bureaucracy. Emperors needed advice and they turned to the eunuchs that surrounded them. The first use of the title Privy Commissioner 樞密使, which would later become Commissioner of the Bureau of Military Affairs, appears in 810. By the end of the ninth century the Commissioners (there were usually two) were close to eclipsing the power of the Chief Ministers and enjoyed privileges previously reserved for non-eunuch ministers.

\footnotetext{
${ }^{33}$ Worthy, "The Founding," 215.

${ }^{34}$ Worthy, "The Founding," 215-16.
} 
This political power and proximity to the emperor was greatly enhanced by the natural affinity of the eunuch Commissioners with the eunuch commanders of the palace armies. A number of eunuchs served successively as military commanders and Commissioners of the Shumiyuan. This made both political sense and military sense, since the close connection between the Shumiyuan and military policy made actual command experience useful. Unlike Li Fuguo's emergency powers, the Tang Commissioners did not have formal authority over the army. They did control the appointments of Army Supervisors, who were usually eunuchs, still another method of extending centralized control over the military. Finally, the Commissioners oversaw campaign planning and more general military policy; Chief Ministers were not included in such deliberations.

The efficiency and centralization of power in the office of the shumiyuan paralleled the institutional structure of the Military Governors that effectively governed parts of North China. Where the emperor used eunuchs, the governors used military officers and personal retainers. When one of those governors became emperor, he slotted his own men into the preexisting imperial administration. This was facilitated by the slaughter of all of the eunuchs in the capital in early 903 by the powerful general Zhu Wen 朱 溫 (852-912). ${ }^{35}$ Zhu would soon overthrow the Tang itself and more formally incorporate the Shumiyuan (albeit under a different name, the Chongzhengyuan 崇政院) into the formal bureaucracy. The new head of the office was Zhu's close personal advisor, Jing Xiang 敬翔 (d. 923). Jing was a literatus, and the office began to be staffed by civil officials. Nevertheless, generals staffed at least one subsidiary position, the Assistant Transmitter of Directives, possibly because it was responsible for communications with the palace armies and with providing military advice.

When Zhu Wen's Later Liang dynasty was overthrown, and a "restored" Tang dynasty reestablished in 923, the Shumiyuan's name was also reestablished and a eunuch placed in charge alongside the new emperor's Chief of Staff, Guo Chongtao 郭崇韜 (d. 926). Guo, like Jing Xiang before him, took over most powers, civil and military, from his position as Commissioner. Guo was later also appointed Chief Minister, though this added nothing to the powers he already held as Commissioner. At least in the context of the Later Tang dynasty, the role of Chief Minister and the civil institutions under the Chief Minister's control were purely executive and scholarly. Guo was succeeded as Commissioner by An Chonghui 安重誨 (d. 931), an illiterate who also drew his power from his closeness to the new, also illiterate, emperor. An became Chief Minister too, and similarly fell from favor and was killed on the emperor's orders.

By this point the power of the Shumiyuan was so great that emperors began to try to gain control of it. During the Later Jin, Sang Weihan 桑維翰 (898-947) became the first jinshi degree holder to serve as Commissioner. Like some of the other Commissioners already mentioned, Sang was the emperor's close councilor who contributed to the new dynasty's establishment. He not only became Chief Minister but later also held the position of Commissioner concurrently. Sang held the dual appointments jointly with another literatus, Li Song 李崧 (d. 948). As literary men rather than generals, they were perceived as being less threatening to the throne, though both were soon pushed out of power through the machinations of a general, who succeeded them.

\footnotetext{
${ }^{35}$ Sima Guang 司馬l光, Zizhi tongjian 資治通鑑 (Beijing: Zhonghua Shuju, 1992), 263.8593-96.
} 
When the general had to step down to go into mourning, the emperor abolished the Shumiyuan and handed its functions over to the Chief Minister.

Here, however, the limitations of the competencies of the Chief Minister came into play. Feng Dao 馮道 (882-954), the Chief Minister, did not believe himself capable of handling military affairs. ${ }^{36}$ Feng was no doubt concerned about the dangers of the position, but he also may well have offered an honest assessment of his own lack of skills. War was a complex business that he had no experience of managing. Feng also claimed that he could not handle both civil and military matters. Whatever the emperor's concerns over his own power, it was probably true that a single individual could not manage all civil and military affairs at every level while being responsible to the emperor.

Civil and military authority was split between the Chief Ministers and Commissioners of the Shumiyuan during the Later Han dynasty, though once again the specific individuals involved diminished the value of the institutional separation. Chief Ministers could discuss military matters, and now competed with the Commissioners for power. When a young emperor succeeded to the throne, the political process became unmanageable. Once again an individual became concurrent Chief Minister and Commissioner, while the other Commissioner, Guo Wei 郭威 (904-54), was allowed to serve as a Military Governor and retain his position in the Shumiyuan. A Chief Minister unsuccessfully opposed this, correctly pointing to the threat of a central government official taking direct control over armies in the field. A Commissioner commanding in the field could take control over those armies because of his central government position. ${ }^{37}$

The Chief Minister's concern was prescient, as Guo Wei did then use his position to overthrow the Later Han and establish the Later Zhou dynasty. After still another round of rewarding with the Commissioner position and then disposing of a main retainer responsible for creating the new dynasty, the Later Zhou began the process of gaining control over the Commissioners for real. Guo's successor split civil and military authority, though even he appointed one individual to concurrently be Commissioner and Chief Minister. This time there was no abuse of power, so perhaps the exception was warranted. At a minimum, however, it demonstrates the critical connection between individuals and institutional structures.

The Song dynasty inherited the split between the Shumiyuan, which matured into the Bureau of Military Affairs, and the civil side of government. Song Taizu strictly maintained the separation of officials controlling these institutions after $964 .{ }^{38}$ As we will see below, he also went to great lengths to create separations within the army structure itself. Taizu's practice continued until the Southern Song, with the exception of the

\footnotetext{
${ }^{36}$ Sima, Zizhi Tongjian, 282.9207.

${ }^{37}$ Central government officials often had concurrent appointments as Military Governors of areas outside the capital, but they had hitherto administered them from the capital. Commissioners did also have occasion to take command of expeditionary forces, which placed them in temporary command for the duration of a specific campaign. A permanent position created the possibility of recruiting and maintaining a force loyal to that governor.

${ }^{38} \mathrm{He}$ had allowed Wei Renpu 魏仁浦 (911-69), who was concurrently Chief Minister and Commissioner under the Later Zhou, to retain both positions until retiring in early 964 . Wei does not appear to have exercised any powers within the Bureau during that time.
} 
Song-Tangut War from 1038-42. In principle, civil and military affairs were divided between the Bureau of Military Affairs and the Secretariat-Chancellery.

Song Taizu, like so many first emperors, was far more militarily accomplished than his successors, as well as being more politically canny. Taizu consulted separately with the heads of the Two Authorities (Liangfu 兩府 / Erfu 二府), preventing a connection at the top of the government between his highest officials. ${ }^{39}$ This was to some extent mitigated by his extremely close relationship with Zhao Pu 趙普 (922-92), his longtime advisor, who had progressed from Commissioner to Chief Minister in 964. Zhao Pu as an individual was far more powerful than his positions indicated, but Taizu zealously guarded the institutional separation of powers he had established. When Zhao Pu and Commissioner Li Chongju's 李崇矩 (924-88) children married, Taizu angrily dismissed Li from his post. ${ }^{40}$ Zhao's move to Chief Minister hardly diminished the centrality of his military advice; he was functionally the architect of the Song conquest, and his appointment was likely an effort to put a loyalist in control over the civil bureaucracy. Zhao was a civil official, inasmuch as he was not a military man, but he was in no way a literary man.

At least by 989, Chief Ministers began to complain to the second emperor, Song Taizong, about their exclusion from both the discussions that the Commissioners had with the emperor and the records of those discussions. Taizong conceded access to the records of the discussions. This was a very limited change and likely had much to do with the failure of Taizong's second campaign to capture the Sixteen Prefectures. Taizong was also even more inclined than Taizu to limit the role of military men in the upper reaches of government because he was less certain of their loyalty to him personally. Cao Bin 曹涁 (931-99), who had been a Commissioner of the Bureau and a field general, also had personal connections to Taizong's younger brother. ${ }^{41}$ All of the founding generals of the dynasty were intermarried with the imperial family, presenting a clear threat to Taizong's position. Members of the imperial clan could not hold regular office during the Northern Song. These connections effectively precluded the highest ranking generals or their sons from service in the Bureau. Quite a few sons and grandsons of founding generals did serve in the army, however, so the rules may only have prohibited men with the imperial surname. The issue is unclear, since our sources mention only the very small number of men who achieved notable success, on top of which only a very small number of men reached the upper ranks of the army or Bureau.

The Bureau itself oversaw critical military and state matters, defense, border preparations, warhorse administration, the transmission and reception of secret orders, all of the duty officers of the Imperial Guard, the recruitment of the imperial armies, and their inspection and testing, troop movements, troop rotation, muster rolls, and matters of

\footnotetext{
${ }^{39}$ Toqto'a, Songshi 162.3798

${ }^{40}$ It seems unlikely that Taizu was unaware of the marriage beforehand, but when a subordinate lodged a charge against Li partly based upon the marriage the emperor could not ignore it without undermining the system he was trying to put in place.

${ }^{41} \mathrm{Cao}$ in fact held a feast for Taizong's younger brother, Tingmei 廷美, as Tingmei was being exiled from the capital for treason, 23.515. Cao was subsequently demoted from his position as Commissioner of the Bureau of Military Affairs, nominally because of he used imperially distributed bonuses to obtain the loyalty of the troops, but also because of his connection to Tingmei. Li, Xu zizhi tongjian changbian, 24.537.
} 
rewards and punishments. It also controlled the tallies necessary to activate and deploy military units. The tallies (sometimes referred to as the "Tiger Tallies") were a critical control over military troop movement. ${ }^{42}$ It was illegal for a commander to follow an order to move troops without the correct tally. This was specifically designed to prevent unauthorized troop movements and was the Bureau's most basic tool to block coordinated mutinies that might threaten the state. Too many people had to sign off on the dispatch of a tally for an individual to seize control of significant forces.

There would ultimately be twelve sections (fang 房) of the Bureau with varying responsibilities. The Northern Section, for example, was responsible for defense of the northern border and the soldiers in Hebei and Hedong circuits. The Capital Section was responsible for the business of the Palace Corps Infantry, the transfer of military equipment, the Chuanshan circuit border defense and security within the capital region, the soldiers in Fujian circuit, Military Commanders and guard troops of the Capital Security Office (Huangcheng si 皇城司). ${ }^{43}$ Other sections combined responsibility for the troops within a circuit with more general bandit suppression, oversight of particular kinds of units like the Baojia 保甲 and Archers, and horses. ${ }^{44}$ Considering that the Song military reached well over a million men in the eleventh entury, simply coordinating, supplying, and keeping track of so many soldiers even in peacetime was a massive task.

During the Song-Tangut war of 1038-42 Fu Bi 富弼 (1004-83) suggested that the Bureau should not be solely entrusted with military responsibilities. Emperor Renzong agreed, allowing the Secretariat-Chancellery to also discuss military matters. ${ }^{45}$ During Emperor Shenzong's reign it was pointed out that the Secretariat-Chancellery and the Bureau frequently disagreed on border affairs. They not only took diametrically opposed positions, in one case with the Bureau criticizing Guo Da 郭達 (1022-88) for repairing fortifications while the Secretariat-Chancellery praised him, but apparently independently issued decrees expressing their respective views. The emperor agreed that in the future they should first reach agreement and only then issue decrees. ${ }^{46}$

Allowing the Secretariat-Chancellery to discuss border affairs meant two civil and military sides of the bureaucracy periodically aired disagreements publicly. Clearly the emperor had not ruled on the matter of Guo Da's work, and the respective sides felt empowered to instantiate their positions by official fiat. Thus the inclusion of the Secretariat-Chancellery in the discussion of military matters had also implicitly allowed it to issue orders and consequently to confuse the chain of command. Presumably Shenzong's approval of the memorial to require agreement before issuing decrees resolved that problem though without, however, indicating which branch would issue the resulting decree.

\footnotetext{
${ }^{42}$ For the "Tiger Tallies" see Li Gang's comments in Toqto'a, Songshi 162.3799.

${ }^{43}$ The Capital Security Office was effectively the secret police charged with monitoring officials and other threats to the throne. It was run by a military officer or eunuch and reported directly to the emperor. Civil officials did complain about it, feeling it unseemly and unnecessary for soldiers to spy on them.

${ }^{44}$ Toqto'a, Songshi 162.3798-99.

${ }^{45}$ Toqto'a, Songshi 162.3799. This was supported by Zhang Fangping 張方平 (1007-91) as well, and the Chief Ministers Lu Yijian 夷簡 (978-1043) and Zhang Dexiang 章得象 (978-1048) were made concurrently Commissioners of the Bureau of Military Affairs

${ }^{46}$ Toqto'a, Songshi 162.3799 .
} 
A second issue of Bureau management arose in 1089, when the incumbent Commissioner, An Tao 安壽 (n.d.), had to step down to mourn the death of his mother. Two officials pointed out that ever since the Song had changed the Five Dynasties' harmful practices and separated the civil and military into the two handles, there had never been a situation in which one person was in charge. It was imperative to appoint another high official to concurrently manage things. This was an expression of concern about both institutional precedent and the concentration of power in a single official's hands. The separation of powers between civil and military sides was not directed against the military side of the bureaucracy per se, so much as against a single official gaining too much power.

The basic argument used to restrict any one official from gaining too much military power was “family rules of the ancestors” (zuzong zhi fa 祖宗之法). In 1126, Li Gang 李綱 (1083-1140), the Administrator of the Bureau of Military Affairs (functionally one of its heads), said that, "In the time of our ancestors, the Bureau of Military Affairs managed the army enlistment rolls, the Tiger Tallies, the Three Commands and various armies, and led the officials who controlled the military handle. Each had a separate area by which it handled military administration. [These are] rules for ten thousand generations that cannot be changed." 47 Similarly, a radical proposal to change the system in 1082 abolishing the Bureau and returning military authority to the Ministry of War was rejected by the emperor since "our ancestors did not return the military handle to that ministry." 48

The emperor's rejection of shifting military power away from the Bureau to the Ministry of War, which was one of the Six Ministries under the civil bureaucracy, ran counter to some of the reform efforts to "rationalize" the government system. ${ }^{49}$ The rationalization was often an effort, at least institutionally, to return the complex mess of Song titles, offices, and prestige titles to their Tang roots where title and office would match. Due either to an antiquarian urge (perhaps fueled by filial piety) or a recognition of the practical difficulties of shifting the military bureaucracy, the emperor preferred institutional conservatism. For the most part, all future modifications to the power of the Bureau were managed by appointing Chief Ministers to concurrently manage the Bureau. However, the Bureau itself was not only constrained through joint appointments of Chief Ministers to head it, but also through multiple Commissioners and Assistant Commissioners (though there were many variations in title). The abiding Song principle was to separate military power from civil power, and to divide military power among several officials.

Li Gang's comments showed just how important those constraints were. Li was a hawkish minister speaking during a time of national crisis. Indeed, the Song capital would be captured, along with the emperor and the retired emperor, the following year. Yet even in the midst of serious military problems Li defended the system of carefully divided control. Arguably, the emperor and his high court officials proved

\footnotetext{
${ }^{47}$ Toqto'a, Songshi 162.3799 .

${ }^{48}$ Toqto'a, Songshi 162.3800 .

${ }^{49}$ Wang Anshi had nevertheless already in the 1070s reduced the overall autonomy of the Bureau by transferring to the Finance Planning Commission much of the power over war, military personnel and military financing, as well as installing his own partisans at the top. See Smith, "Shen-Tsung's Reign,” 373.
} 
inadequate to the events they faced in 1126 and 1127 , so the system did not, in and of itself, work out very well. ${ }^{50}$ No system could prevent incompetent leadership. Li Gang, although a civil official, was aggressive and militant to a fault. Civil officials had never lacked belligerence or interest in going to war.

The Bureau would remain essentially intact for the rest of the Song dynasty, though its relationship to the army would change during the Southern Song. With the fall of North China to the Jurchen Jin, the Song military changed drastically. As will be discussed below, most of the frontline armies of the Song, along with the navy, which became absolutely critical in the defense of the empire, were controlled by four regional border commands running from Sichuan down the Huai River to the coast. The commanders of these border regions wielded immense local power in ways somewhat similar to the Tang or Five Dynasties periods. Border commanders were allowed considerable autonomy in return for fending off the Jurchen and later the Mongols. Their immense military power made them an obvious threat to the throne, and there was a constant political balancing act between the capital and the border. Once again the challenge was to maintain the loyalty of critical military men without allowing them to bully the imperial court.

Over the course of Song history, the institutions of the Bureau balanced internal security with border defense. It did not make or control military policy isolated from the emperor or even other high officials. With very few exceptions, it was concerned with defense rather than planning campaigns. The Song did not expand very much after 1005 , and the early years of conquest were not part of standard bureaucratic routine. It was very successful in preventing, or at least not creating conditions conducive to, mutinies. There was one mutiny in 965 after the Song conquest of the kingdom of Shu caused by new military discipline, but it did not threaten the throne.

There were more serious mutinies during the Southern Song, which convinced the emperor if he needed convincing that powerful generals were a fundamental threat to the throne. Even seemingly loyal generals could not fully be trusted. One sign that the Bureau was less critical during the Southern Song was that in 1141 when Song emperor Gaozong wanted to diminish the power of the border generals he promoted Han Shizhong, Zhang Jun, and Yue Fei into the Bureau and therefore away from their troops. All three men accepted the promotion, understanding that the nature of the situation required their removal. To resist the promotion would have shown disloyalty and made them into a real threat. Han Shizhong did openly oppose the peace negotiations and was forced to retire.

The Bureau of Military Affairs was directly concerned with the military, but during the eleventh century it became almost exclusively staffed at the higher levels by men with either civil exam degrees or educated men with non-military backgrounds. Very few military officers were able to move into the upper, or even middle, ranks of the Bureau. This was mostly a consequence of the transformation of the military bureaucracy into a massive edifice of paperwork. While it was possible for a high-ranking military officer

\footnotetext{
${ }^{50}$ A more serious but unexamined issue is the erosion of the Song military leading up to the crises of 112627. It has mostly been subsumed under the corruption of Song emperor Huizong's reign (1100-1126), but may well have begun earlier. At a minimum, there were surprisingly few troops in the capital when it was attacked.
} 
to move into the ranks of the Bureau, it was infrequent. A bureaucracy required literate bureaucrats, not field commanders.

The dominance of the military bureaucracy by non-military men and civil exam degree holders appears on the surface to be a concrete example of civil predominance in Song government and culture. Members of the civil bureaucracy fought hard and successfully in the early Song to be consulted about military affairs. Consequently, civil bureaucrats controlled every aspect of the bureaucracy at the administrative level, and most of the executive level even within the military bureaucracy. There were very few men with real experience of the army or battlefield formulating policy at the Song court.

Of course, the very few men with real military experience were consulted when needed. The availability of competent and experienced generals varied tremendously across the Song. By the early eleventh century the experienced generals were dead, leading to the initial efforts to establish a formal military education system in the 1030s. When the Xi Xia attacked in 1038 the empire had been at peace for more than thirty years. The military was unprepared for the war and performed poorly. The army's performance only improved after years of trial and error, but the cessation of fighting and a formal peace ended efforts at revitalization. Deep problems in the military were revealed, resulting in some reorganization of tactics, command, and force structure, but the extent and effect of those reforms is unclear.

One of the few successful generals of that period, Di Qing 狄青 (1008-57), was promoted into the Bureau of Military Affairs precisely because he had battlefield experience. His promotion was greatly facilitated by his patron Fan Zhongyan 范仲淹 (989-1052), a prominent civil official, and by his pursuit of a literary education. It was not that becoming educated made him able to hold a bureaucratic position, but rather that the act of becoming educated demonstrated an appreciation of literati values. Literati officials were deeply suspicious of men who did not share their values, primarily the superiority of highly literate men with a Confucian education. This became far more of an issue during the Southern Song, when civil-military relations were far more critical.

A connection is often made between the perceived poor performance of the Song military and the dominance of literati officials in the Bureau. This view largely ignores the actual functions of the Bureau. Military policy was made in the State Council where literati officials were just as often hawks as doves. The New Policies under Shenzong were intended to strengthening the state and its military to defeat the Tanguts and then the Liao. These policies were carried out, and some gains in territory were made, but the cost of the campaigns against the Tanguts in men and material made it clear that a major effort against the Liao was impossible or at least would require a far greater effort than the Song court was willing to make.

Although the literati officials serving in the Bureau were civil, their functional service in the military bureaucracy involved them in military matters. As much as this was a sign of civil dominance of military matters, it was also a sign of military matters dominating government policies. The fate of the dynasty did not turn on debates over ritual or poetry; it relied upon an effective military. Furthermore, in war the military instrument also requires effective strategy. The Bureau and its civilian bureaucracy were partly effective during the Northern Song because of policy decisions made by the emperor with his top officials, civil and military, and the circumstances they were forced to respond to. At no time, however, was there an effective leadership group of generals with a completely 
different set of policy responses who were excluded from power. Civilian officials argued for the full range of policy responses in every circumstance, from the most bellicose to the most pacifistic.

\section{THE ARMY}

The structure of the army, both its bureaucracy and its units, was completely populated by military officers. Its larger organization balanced centralization of power in the hands of the emperor against unity of command for battlefield effectiveness. Functionally, the formal structure was truncated through personnel management, leaving vacant positions that would have unified the imperial armies under a single officer. Unlike the Bureau of Military Affairs, the actual army, and the navy (though they were not separate services), could not substitute literati for military men. It is likely that literate clerks assisted with the paperwork that most army units would have required, but we have no mentions of them. The majority of soldiers and officers were illiterate, and most of those who were functionally literate were not highly educated. The ability of the famous general Cao Han 曹翰 (924-92) to compose a poem at court on one occasion surprised the emperor and his civil officials. ${ }^{51}$

Armies are not measured on their literary skills, but on their fighting abilities. Unfortunately, we are nearly as uninformed about the tactical training and organization of the Song army as we are about its bureaucracy. The basic weapons of the army were swords, spears, bows, and crossbows. The later addition of gunpowder weapons, fire spears, grenades and bombs, fire arrows, and even guns does not appear dramatically to have changed the tide of battle. Government arsenals manufactured gunpowder and gunpowder weapons, and at least in the early Northern Song period this was under the Office of the Eight Crafts. ${ }^{52}$ Later in the Northern Song at least some cities and forts had their own arsenals that produced gunpowder weapons (or were supposed to). ${ }^{53}$ The government controlled large-scale arms production more generally as a way of maintaining civil order and preventing armed uprisings. However the effect of that control is less clear and there is at least visual evidence in the Song-period scroll painting Qingming Shanghe Tu (Spring Festival Along the River) of a private market in bows.

Song armies recruited men and trained them to fight, with the likely exception of the non-Han forces used on the border. In this respect the Song army was similar to the Tang and Ming armies, where Chinese men were recruited and trained, and non-Chinese units, usually cavalry, were hired as pre-trained and armed forces. The Five Dynasties armies that became the Song armies were extremely efficient and effective forces after years of continual warfare. It became increasingly difficult to maintain military effectiveness after the end of the wars of conquest in 1005 . Veteran soldiers and officers retired or died leaving a peacetime army without real experience of war. At its most basic level of training, Song soldiers trained to respond to drums and gongs, and to function as a unit. Soldiers needed to stand, sit, advance, retreat, and loose arrows on command. Infantry and

\footnotetext{
${ }^{51} \mathrm{Li}$ E 厲鶚 and Ma Yueguan 馬曰琯 (eds.), Songshi jishi 宋詩紀事, in Guoxue jiben congshu 國學基本叢 書 (Taibei, 1968), 2.10b.

${ }^{52}$ Xu Song 徐松, Songhuiyao jigao 宋會要輯稿 (Taibei: Xinwenfeng chubanshe, 1976), 2981.

${ }^{53} \mathrm{Xu}$ Song, Songhuiyao jigao, 3143.
} 
cavalry had to coordinate their actions in support of each other. Soldiers who trained daily were paid more than soldiers who trained less frequently. ${ }^{54}$

The basic organization of imperial army units started with the company ( $d u$ 都) of 100 men. Five companies formed a battalion (zhihui 指揮) or garrison (ying 營). Five battalions formed an army (jun 軍). Ten armies formed a wing (xiang 廂). The battalion was the most basic administrative unit during the Northern Song, with individual battalions formed in specific places and times. ${ }^{55}$ The actual number of soldiers in a given unit varied enormously over time and with the importance of the unit. More prestigious units closer to the capital and the throne were likely closer to their paper strength; there was no guarantee, for example, that a unit designated an army would have had five battalions, or that those battalions would have been at full strength. Our only fragment of hard data on battalion strength shows a fair range of enrollments. ${ }^{56}$ Particularly in peacetime, a commander might be inclined to have an understrength unit in order to pocket the salary for the missing soldiers.

The imperial armies themselves were divided into upper, middle, and lower armies. The Upper Four Armies (Shang sijun上四軍) stationed at the capital were divided among three different command structures. ${ }^{57}$ The Solar Supporter (Pengri 捧日) and Heavenly Martial (Tianwu 天武) armies were under the Palace Command, the Dragon Guard (Longwei 龍衛) army was under the Metropolitan Cavalry Command, and the Divine Majesty (Shenwei 神衛) army was under the Metropolitan Infantry Command. Other units rotated from the capital to the border on a regular basis until well into the eleventh century, when the cost of the practice was perceived as excessive and unnecessary. The basic organizing principle was that the Song capital should always maintain as many troops as were posted outside the capital in the various garrisons. For Northern Song rulers, a strong capital force would prevent a repeat of the An Lushan Rebellion, when border troops rebelled and captured the Tang dynasty capital. The Upper Four Armies were more likely to be maintained at full paper strength than other field units.

Officers fell into two categories, attached and unattached. Attached officers were those assigned to specific battalions. These men were under the authority of the Three Offices (Sanya 三衙). Unattached officers fell under the authority of the Bureau of Military Affairs. Becoming unattached was a promotion that allowed the officer to be given tasks in civil or military administration or command of an expeditionary force. The highest-ranking officers were thus not in regular command of troops and were under the government's tight control. Higher-level administrative units above the battalion level were organized for bureaucratic rather than operational purposes.

The provincial armies grew out of the centralization process. Armies based in local districts fed their best troops into the imperial armies and absorbed substandard troops back from the imperial armies. This process began during Zhou Shizong's 周世宗 reign and accelerated under Song Taizu. Its institutionalization weakened garrison forces outside

\footnotetext{
${ }^{54}$ Toqto'a, Songshi 195.4853 .

${ }^{55}$ See Wang Zengyu, Songchao bingzhi chutan, 34-54, for a list of the names of individual battalions as well as the locations and times of their creation.

${ }^{56}$ Bao Zheng 包拯, Bao Zheng ji 包拯集, ch. 8: “Qing yi ji, bo, shen, san zhou bingma," cited in Wang Zengyu, Songchao bingzhi chutan, 29-30.

${ }^{57}$ Toqto'a, Songshi 187.4579.
} 
of the capital, making them less of a military threat while still being sufficient for policing and labor, as well as providing a living for declining soldiers. The Song government then made it a general policy to use the provincial troops for public works projects that would otherwise have used corvée labor from the farming population. Like the local militias, they proved of to be of little value in war. Imperial troops had to defend the border, and it was the initial failure of imperial troops against the Tangut Xi Xia invasions beginning in 1038 that led to the first serious government reform effort, the Qingli Reforms. These reforms were short-lived, but foreshadowed the New Policies of Emperor Shenzong.

There were two areas of military reform in the Yuanfeng period (1078-85), within the bureaucracy and within the army. Bureaucratically, as Winston Lo described it, "the Yuanfeng reorganization imposed a uniform terminology on the rank systems of both the civil and military officials and brought them under the same personnel agency. The barriers that used to separate them were therefore reduced and the psychological distance between them was shortened. On the other hand the Yuanfeng reorganization also had the effect of weakening the ties between the many military rank officials and the military establishment." ${ }^{58}$ Seen from a civil perspective, this narrowing of differences between civil and military officials appeared to be a sign of civil dominance. The military officials had become more like civil officials. However, the number of military officials did not diminish, nor did their responsibilities change. Thus, in structural terms, military affairs' significance actually grew. Much of the Song government was fundamentally militarized and remained so throughout its history.

There were three major reforms within the army itself. First, on Su Shi's recommendation, the system of rotating troops between the capital and the border every three years ended. Second, in 1074 troops were organized into commands (jiang 將) of approximately three thousand men that could be made up of different kinds of units. These larger units were supposed to be more effective because they trained together, though there was no noticeable improvement in performance in the field. Third, all of the households in the empire were to be organized into the Baojia 保甲 ("tens and hundreds") system. The Baojia system was a militia system that organized and trained adult males for military service. It was based upon households, thus also functioning as a mutual surveillance policing system. Although it was intended ultimately to replace the imperial army with a far larger and much cheaper militia, it too did not prove effective in its military function. .59

After the fall of North China, the Song government struggled to reform its army structure. It proved impossible simply to renew the earlier institutions, forcing the court to recognize and exploit emerging new de facto practices. Most obviously, the balance between capital and border forces shifted dramatically toward the border forces. The generals commanding those border forces became far more powerful than was possible during the Northern Song. There would be no rotation of imperial army units from capital to border and back.

The remnants of the imperial armies became provincial forces of limited military value. In their home regions, some locally raised forces became highly effective at

\footnotetext{
${ }^{58}$ Lo, Introduction to the Civil Service, 73.

${ }^{59}$ For an overview of the Baojia system see, Smith, "Shen-Tsung's Reign," 407-14.
} 
bandit suppression, even resisting Jurchen or Mongol raiding. Their local successes sometimes convinced the court to draft them into frontline action against the Jurchen or Mongols. Unfortunately, they were not only less effective outside of their limited local functions, but their withdrawal from their home areas opened those places up to banditry. ${ }^{60}$ The dynasty's survival came to rest on the navy and the armies of the four military regions along the Huai River and the forces in Sichuan.

The chronic military threat made the military central to Southern Song external concerns and consequently raised the status of soldiers. Soldiers in the Southern Song received better treatment, reversing the immiseration of the Northern Song military class. ${ }^{61}$ The border generals were in a far stronger position to recruit, train, and retain the services of capable soldiers and officers. Even in the capital the relatively small number of soldiers (compared to what was on the border) were of far greater importance in protecting the court from internal threats. The court could not allow the forces directly defending it to become disaffected.

During the Southern Song, opportunities to rise from the botton to the top of the military increased markedly. In the Northern Song, founding generals were often the sons of military men in the preceding period. Their sons in turn often ended up as Song officers, some even reaching high rank. A good example of this was Cao Bin, whom I discussed above. Cao was the son of a Five Dynasties general, and his son, Cao Wei 曹瑋 (9731030), also became an important Song general. By contrast, Di Qing, also mentioned above, enlisted as a soldier, was tattooed on his face, and rose through the ranks of the army, eventually being promoted to Assistant Commissioner of the Bureau of Military Affairs. General Di was probably the most extraordinary military figure of the Northern Song, the rare example of someone born a farmer, who enlisted and reached the highest ranks of the Song government. Other less notable men may have risen from the bottom into the middle ranks of the army and possibly the Bureau as well.

Several generals who saved the Southern Song, like Han Shizhong, and Yue Fei, were also born into farming families but rose through the ranks of the military to the top through their military accomplishments. By contrast, the Lu family that controlled so much of the Southern Song border was a fully reticulated patronage and descent group that had power over most personnel decisions within its areas of responsibility. In chaotic times like the beginning of the Southern Song it was possible for a farmer to reach the top of the military hierarchy. Yet even during the eleventh century, no formal rules barred a farmer moving all the way to the top. Wars allowed rapid promotion, but connections were always helpful, and military families could train their sons to be officers. In this sense, although the sons of generals had many advantages, merit could at least sometimes win out.

\section{CONCLUSION}

The Song dynasty has long posed a seeming contradiction to historians. The period is renowned for extraordinary cultural, scientific, and economic development but notorious

\footnotetext{
${ }^{60}$ Huang Kuan-Chung 黃寬重, Nansong difang wuli 南宋地方武力 (Taibei: Dongda tushu gongsi, 2002).

${ }^{61}$ Alyagon, "Inked."
} 
for its military weakness. Many modern historians offered an elegantly simple explanation: literati dominance of Song government and culture restrained the society's natural military potential. This explanation echoed modern Chinese feelings about China's failure to defend itself against the imperialist west in the nineteenth and twentieth centuries. Broad characterizations of institutional history are often part of a narrative describing something else. Explanations of why the Song was culturally strong and militarily weak likely owe something to scholars' use of the past to criticize the present.

Yet the argument breaks down when we take a step back and examine the idea of the Song as a civil or "Confucian" dynasty in contrast to other dynasties. ${ }^{62}$ This does not question the literati argument that the Song was a particularly civil or Confucian dynasty. Many contemporary literati in fact did argue that the Song was a particularly civil or Confucian dynasty; they may well have believed it. Thus, modern scholars are correct to point out that Song literati felt that civil officials and civil culture dominated the court. But there is no reason simply to accept Song literati assertions at face value. The Song government, unlike the Tang government, explicitly constructed an institutional framework that made the military one of the Two Authorities of government bureaucracy. Literati officials working both in the Bureau of Military Affairs and in the upper ranks of the SecretariatChancellery discussed, proposed, and managed military matters. In short, they were heavily involved in military matters despite their backgrounds and self-perceptions.

Song culture was also far more martial than most literati writings would have us believe. Literati authors wrote about matters that were more important to them, and imagined the world to revolve around their own values. These writers, however, were a tiny fraction of the Song population; few people outside of their ranks were concerned with or even aware of their interests. In contrast, public performances of martial arts, which grew common during the period, exercised a far more pervasive influence on non-elites and popular culture than did Neo-Confucian debates on ritual. Literati themselves advocated for the creation of military exams and, as part of that process, wrote or compiled many works on military thought. None of this makes sense if we imagine the Song as a time a civil dominance wherein the military was a marginal arena of little interest to society. The institutional perspective makes the centrality of the military and martial concerns absolutely clear. At a minimum, after all, soldiers always far outnumbered civil officials.

If Song literati officials were neither less warlike than military men nor Song culture so overwhelmingly civil as to cripple the army and military policy at a fundamental level, then there must be some other explanation for the army's disappointing performance. Setting aside the historiographical issues on the construction of Song weakness, we are left with the basic problems of strategy, policy, and organizational ability. ${ }^{63}$ The Song army was not consistently ineffective and incapable, even if it suffered battlefield and operational setbacks in the early stages of several wars. It prevented the Tanguts from winning in the 1038-42 war, an important achievement given that the Song goal was defensive. When the court felt wealthier and stronger, it launched a devastating campaign

\footnotetext{
${ }^{62}$ Kuhn, The Age of Confucian Rule.

${ }^{63}$ I do not intend to belittle the historiographical issues here, which are considerable. Even a passing discussion of the construction of Song weakness, however, would require an article in its own right. For some preliminary discussions of the issue see, Labadie, "Rulers and Soldiers," 11-12; Peter Lorge, The Reunification of China: Peace Through War under the Song Dynasty (Cambridge: Cambridge University Press, 2015), $20-21$.
} 
against the Tanguts in 1081. This latter offensive was not seen as a great success because of its huge costs and failure to destroy the Tangut state completely, but it did immense damage to the Tanguts.

The Song-Tangut wars of the eleventh century highlight the limits of military power and the critical role of the emperor in military policy. Emperors decided questions of war and peace and chose their officials to suit their own predilections. The literati as a class, particularly those in high government office, were extremely influential, but they were never monolithic nor the sole force driving policy. At the same time, just because the Song was a large and powerful state did not mean that it could erase the limitations of logistics or human willpower. It is never clear how much damage will force an opponent to make concessions, or if either side is willing to pay the costs to reach that uncertain outcome. The Song court may have been too willing to back down or unwilling to pay the costs of further fighting. Many emperors and their councilors made mistakes in policy. Just as often, they did not understand the operational limits of their military and paid insufficient attention to the maintenance of that military instrument. But this was hardly unique to the Song dynasty or even China.

Ultimately the institutional argument is an attempt to set aside the contingent events of war, diplomacy, politics, and personalities. What studying Song military institutions tell us is that there is no simple institutional argument that explains Song history. A highly developed military bureaucracy managing a large and sophisticated army could not, in and of itself, solve the succession of military problems the Song dynasty faced. Those military problems were critically important to emperors and officials of all stripes. There was no characteristically "Confucian" military policy, for better or worse. Just as effective military policy was not undermined by civil culture, so too we must recognize that the military and martial culture was at least as prevalent and influential, if not more so, in Song society as the civil bureaucracy and literati culture. The obvious reflection of that was the extent of the military institutions of the Song government. 